\title{
The preparation, training and support requirements of expatriate trailing spouses
}

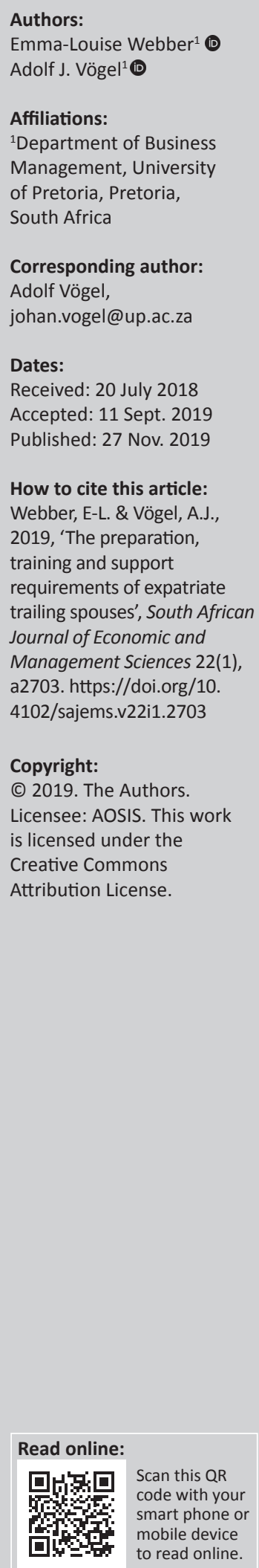

Background: Decades have passed since trailing spouses were first identified as the primary causes of expatriate failure. This has led to numerous studies to determine how best to avoid such failures. In particular, it was determined that through the preparation, training and support of trailing spouses multinational enterprises (MNEs) can not only assist with their adjustment to the host country, but also reduce the likelihood of expatriate failure.

Aim: With the impact of the trailing spouse still being a major concern for the success of an international assignment decades after it was first identified as such, this research aimed to determine the preparation, training and support requirements of trailing spouses prior to, and during an international assignment.

Setting: The article includes the responses from trailing spouses who at the time of the study were on assignment in 52 countries on six continents.

Methods: Both non-probability judgement sampling and snowball sampling were used to identify the 218 respondents who completed a self-administered questionnaire which respondents were able to access online. The data was then analysed using exploratory factor analysis, Cronbach's alpha, a $t$-test and paired $t$-test.

Results: Statistically significant differences were found between the preparation, training and support required by trailing spouses and what was offered to them by MNEs for all the specific forms of preparation, training and support measured in this study.

Conclusion: MNEs are still falling short of the preparation, training and support needs of trailing spouses. In particular, MNEs seem to focus on some operational aspects of spousal adjustment while the social aspects are still not sufficiently addressed.

Keywords: Expatriates; International assignments; Trailing spouses; International human resource management; Adjustment; Preparation; Training; Support.

\section{Introduction}

The inability of an expatriate's spouse to adapt to the host country has consistently been found to be the most common cause of expatriate failure (Anderson 2005:568; Briscoe, Schuler \& Claus 2009:165; Haile, Jones \& Emmanuel 2007:101; Tung 1981:76). Expatriate failure can be defined as the underperformance by the expatriate during the international assignment, the premature return of the expatriate, or repatriate failure on returning to the home country (Briscoe et al. 2009:180; Harzing \& Van Ruysseveldt 2004:274; Shen 2005:657; Swarts \& Du Plessis 2007:48; Templer 2010:1754). This can be attributed to the fact that spouses are confronted with obstacles in the host country, such as culture shock, isolation, differences in work-related norms, health care systems, housing and schooling (Andreason 2008:386; Briscoe et al. 2009:185; Mendenhall, Dunbar \& Oddou 1987:331).

Although expatriate spouses are likely to be less sheltered from the foreign environment and more exposed to the culture than the expatriates and in some cases even the accompanying children, they tend to be excluded from selection and training processes and receive less incountry support, making it harder for them to adjust (Andreason 2008:382-387; McNulty 2012:418; Tung 1982:65; Wilson 2011:9). Deen (2011:10), Harvey and Moeller (2009:280) and Haslberger and Brewster (2008:2008) acknowledge that these obstacles tend to create high levels of stress and tension for spouses, leading to conflict within the family and affecting the expatriate's morale and ability to perform their job effectively. Many multinational enterprises (MNEs), however, fail to recognise the relationship between expatriate success and the trailing spouse's adjustment, and as a result they neglect to include the spouse in the expatriation process. In fact, according to Cartus 
and Primacy (in McNulty 2012:421), MNEs' interest in providing assistance to expatriates' trailing spouses and families is on the decrease with only $13 \%$ of enterprises being interested in improving these assistance programmes. Consequently, it is not surprising to note that overall organisational support continues to disappoint trailing spouses (McNulty 2012:430; Selmer \& Leung 2003:17), with trailing spouses believing that MNEs are not genuinely interested in their wellbeing (McNulty 2012:430).

In fact, between $80 \%$ and $90 \%$ of expatriates are accompanied by their spouses (Ali, Van der Zee \& Sanders 2003:564; Van Erp et al. 2011:58; Wu \& Ang 2011:2690) but only 50\% of MNEs offer some form of support for trailing spouses, $87 \%$ of which provide assistance only when necessary. This while as little as $13 \%$ have formal policies in place regarding trailing spouses (Briscoe et al. 2009:183).

Thus with the impact of the trailing spouse still being a major concern for the success of an international assignment decades after it was first identified as such (Tung 1982), this research aimed to determine the preparation, training and support requirements of trailing spouses prior to and during an international assignment.

This article contributes to the existing literature as it contributes to McNulty's (2012:432) call for more quantitative studies on the topic, and in doing so it develops our knowledge of this field.

\section{Literature review}

Spousal support of the expatriate, the assignment, and their adjustment and satisfaction during an international assignment is considered crucial for assignment success (Cole 2012:309; Long 2010:75; Wang, Bullock \& Oswald 2011:74). Consequently, Gupta, Banerjee and Gaur (2012b:26) and Vögel and Van Vuuren (2008:80) emphasise the importance of spousal preparation, training and support prior to and during the international assignment.

\section{Preparation requirements}

A survey by CIGNA International (Brown 2008:1030) found that $53 \%$ of enterprises felt they provided sufficient preparation for expatriate families, while only $32 \%$ of expatriates felt that their families received adequate preparation and support prior to and during the international assignment. Cherry (2010:133) and Dewald and Self (2008:357) state that the involvement of the spouse in predeparture preparation regarding the assignment, including supplying them with information on the foreign country's culture and living standards, aids in their general adjustment. While the opposite is also true, spouses with unrealistic expectations soon become dissatisfied with the country, culture and living conditions, which inhibits their crosscultural adjustment and often results in the family's premature return (Kim \& Tung 2013:1042). Consequently, enterprises should provide families with a realistic preview of everyday life in the host country, as well as accurate and up-to-date information about the country, its people and culture (Cherry 2010:139; Kim \& Tung 2013:1045; PurgalPopiela 2011:39; Vögel \& Van Vuuren 2008:85).

In particular, Cascio (2006:645), Sharma (2012:15) and Vögel and Van Vuuren (2008:85) recommend that enterprises organise orientation visits to the host country for potential expatriates and their spouses before their final departure. These orientation visits provide expatriates and their spouses with invaluable first-hand information regarding the host country and culture, which may reduce spousal uncertainty and aid in the spouses' adjustment during the assignment (Ghafoor et al. 2011:338; Rosenbusch \& Cseh 2012:63; Sharma 2012:15; Sims \& Schraeder 2004:76).

The opposite can, however, also be true, with Harvey and Wiese (1997:368) and Sims and Schraeder (2004:76) warning that the pre-departure orientation visit can become a 'tourist' visit or holiday, leaving the expatriate couple with an unrealistic perception of the host country's culture and customs. As a result, the couple can experience severe culture shock on their arrival in the host country, as they realise that the culture and lifestyle they experienced on their orientation visit differs significantly from the reality.

Additionally, it has been suggested that enterprises should offer relocation, housing and placement assistance, and provide expatriates and their spouses with lists of property agents, appropriate schools, shopping centres and medical clinics prior to the assignment (Cherry 2010:139; Kim \& Tung 2013:1045; Purgal-Popiela 2011:39).

Kupka, Everett and Cathro (2008:1774), however, found that the majority of trailing spouses were rarely prepared for the foreign environment they were to encounter. As a result, the following hypothesis was stated:

$\mathrm{H}_{1}$ : There is no difference between the preparation required by trailing spouses and the preparation provided to them by the multinational enterprise prior to the assignment.

\section{Training requirements}

The trailing spouses' need for training prior to their departure is emphasised throughout the expatriate literature (Fischlmayr \& Kollinger 2010:471; Mohr \& Klein 2004:1197; Smart 2011:64; Vögel \& Van Vuuren 2008:85). Expatriates and spouses who are prepared for and aware of the host country's religious, cultural, language, and lifestyle differences, will have a mental idea of potential situations that may arise during the assignment. This mindset of being prepared should increase their confidence in the assignment, eliminate uncertainty, and ease their adjustment in the local environment, reducing the chance of premature return (Cho, Hutchings \& Marchant 2013:1053; Gupta et al. 2012b:18). In particular, this training should include a focus on both objective and subjective characteristics of the foreign culture, with the objective characteristics focusing on tangible and observable characteristics such as architecture, language and 
currency, while the subjective characteristics will focus on intangible characteristics such as values, norms and beliefs (Shay \& Tracey 1997:34-35).

According to Shaffer and Harrison (2001:243), differences in the host country's language and cultural novelty will, however, have a greater impact on the accompanying spouse than on the expatriate, with cultural novelty defined as 'commonplace features or everyday customs' of a country's culture. Spouses often struggle to adjust as they become confused, stressed and overwhelmed by their lack of knowledge and understanding of the new, foreign culture and its customs (Caligiuri, Tarique \& Jacobs 2009:257; Ghafoor et al. 2011:337; Gupta, Banerjee \& Gaur 2012a:3560; Van Erp et al. 2011:75). While expatriates have the stability of a familiar work environment, the spouse tends to be more immersed in the local culture on a daily basis, interacting with locals who may not speak their language and who are not accustomed to dealing with foreigners (Andreason 2008:386; Cole 2012:313; Purgal-Popiela 2011:33; Wilson 2011:9).

Kupka et al. (2008:1783) and Mohr and Klein (2004:1194) found that spouses who acquired a basic repertoire in the foreign language had a more positive international experience, and adjusted more easily than those who made no attempt to learn the language. Language and communication problems create social barriers, making it difficult to cope with everyday tasks, form friendships, find employment, and adjust and integrate with the locals (Cherry 2010:137; Kim \& Tung 2013:1033; Purgal-Popiela 2011:38; Rosenbusch \& Cseh 2012:73; Sharma 2012:16). Enterprises should therefore provide relevant predeparture and post-arrival training, to assist spouses with adjusting to the host culture and language, and with developing social competences and networking skills (Cherry 2010:140; Lund \& Degen 2010:70; Okpara \& Kabongo 2011:29).

Spouses in general, however, do not receive relevant predeparture training from MNEs, and are sent to the host country unprepared, without any briefing about the new culture they will experience (Gupta et al. 2012b:17-21; Lund \& Degen 2010:70; Mansour \& Wood 2010:387; Rosenbusch \& Cseh 2012:63). Sims and Schraeder (2004:76) found that many managers believe that pre-departure training for expatriates and their spouses is expensive, time consuming, and often ineffective in reducing culture shock. As a result, due to previously high expatriate failure rates multinationals are unwilling to invest in such training programmes. Consequently, programmes that do exist tend to be ineffective and run by unqualified individuals (Lund \& Degen 2010:70).

As a result, the following hypothesis was stated:

$\mathbf{H}_{2}$ : There is no difference between the training required by trailing spouses and the training provided to them by the multinational enterprise prior to the assignment.

\section{Support requirements}

International assignments usually require trailing spouses to give up the current and familiar structure and stability in their lives, increasing their uncertainty and stress levels and inhibiting their ability to adjust (Cherry 2010:133; Cho et al.
2013:1052; Wilson 2011:38). One of the primary stressors for trailing spouses is the anticipated loss of social support provided by family and friends in the home country. This lack of support increases the spouse's feelings of isolation, which has been known to cause conflict within the family, resulting in decreased spousal adjustment and expatriate productivity (Cherry 2010:133; Crowne \& Goeke 2012:10; Mäkelä, Känsälä \& Suutari 2011:190; Mohr \& Klein 2004:2004; Smart 2011:31; Wilson 2011:38).

Trailing spouses therefore require strong social support from host nationals as well as the enterprise, in order to successfully adjust in the host country and to reduce failure that often occurs within the first year of an assignment. According to Cole (2012:313), Fischlmayr and Kollinger (2010:472), Long (2010:178), Wilkinson and Singh (2010:178), and Wilson (2011:17-18), social support has a significant effect on psychological well-being and personal growth, reducing uncertainty and allowing spouses to get advice from host nationals, form friendships, and share experiences with likeminded people.

Additionally, recent trends have indicated that the number of dual-career couples sent on international assignments is growing significantly. A dual-career couple is a couple where both the husband and wife are employed, psychologically committed to their work, and earn an income for the family (Konopaske, Robie \& Ivancevich 2005:408; Mäkelä et al. 2011:186).

Dual-career couples are often faced with many issues and problems when an expatriate manager accepts an international assignment. These problems often arise when trailing spouses seek employment in the host country, as spouses are often unable to find suitable or satisfying work, or are ineligible to work in host countries with conservative cultures. When giving up their careers, trailing spouses experience role changes and feel a loss of identity and selfesteem. The anticipated loss of additional income and career development may also reduce the expatriate family's living standards, and lead to disagreements within the family (Cho et al. 2013:1053; Lauring \& Selmer 2010:61; Shaffer et al. 2012:1295). The resultant stress experienced by spouses in this situation often has a crossover effect on the expatriate's work performance and adjustment, increasing the likelihood of failure (Gupta et al. 2012a:3560; McNulty 2012:421-422; Rosenbusch \& Cseh 2012:63).

Alternatively, Andreason (2008:388) and Rosenbusch and Cseh (2012:63) have found that spouses who do not experience a change in their employment status adjust more easily on an international assignment.

Consequently, enterprises can provide trailing spouses with employment assistance, as spouses who are employed in the host country receive social support, and learn culture-specific behaviours from their host-national colleagues in the workplace. Enterprise assistance may include the creation of 
a position within the foreign subsidiary, assistance with obtaining the necessary work permits, recommending the spouse to other enterprises operating in the host country, or the payment of a spouse's further education expenses (Cole 2012:313; Mäkelä et al. 2011:188; Vögel \& Van Vuuren 2008:85; Wilson 2011:67)

Kupka and Cathro (2007:960) have, however, found that only $10 \%$ of trailing spouses who were employed in the host country were assisted by the enterprise in their job search, while $85.7 \%$ of spouses struggled to obtain work by themselves. In a study by McNulty (2012:428) it was found that due to visa or work permit restrictions only $36 \%$ of trailing spouses were able to continue with their careers in the host country.

In light of these facts, expatriates often refuse an international assignment or their spouse may refuse to accompany them as they are committed to their own careers (Cho et al. 2013:1053; Els 2007:23; Fischlmayr \& Kollinger 2010:458; Mäkelä et al. 2011:188). A statement supported by Cartus (in Wilson 2011:22) reported a $6 \%$ decrease in enterprise spousal support programmes between 2007 and 2010, which was accompanied by a $15 \%$ decrease in the number of trailing spouses who accompanied expatriates on international assignments.

As a result, Forster (1997:427) states that MNEs should therefore provide support for the spouse during the assignment, in the form of employment assistance, mentoring programmes, expatriate communities, enterprise social gatherings, health clubs, or regular visits back home, to reduce stress associated with adjusting to an unfamiliar environment. Enterprise assistance may also include housing, shopping, schooling advice, counselling, stress monitoring, and supporting work-life balance by introducing the family to leisure, social, and cultural activities (Cole 2012:313; Crowne \& Goeke 2012:10; Gupta et al. 2012b:1; Lauring \& Selmer 2010:61; Rosenbusch \& Cseh 2012:63; Wilkinson \& Singh 2010:173-174). As a result, the following hypothesis was stated:

$\mathbf{H}_{3}$ : There is no difference between the support required by trailing spouses and the support provided to them by the multinational enterprise during the assignment.

\section{Methodology}

\section{Measuring instrument}

The research was preceded by a comprehensive study of the expatriate literature in order to determine the preparation, training and support requirements of expatriate trailing spouses, before and during an international assignment. Qualtrics - a system used to create online surveys (Qualtrics 2019) - was then used to construct a self-administered questionnaire which respondents were able to access online through a link contained in an email.

The questionnaire contained 34 demographic questions and 22 statements linked to a four-point Likert scale. The 22 statements were divided as follows: five statements related to preparation, four statements related to training and 13 statements related to support. These 22 statements were displayed across two columns, one column to measure what trailing spouses felt was required by them in order to adjust and the other to measure whether they received this from the MNE.

\section{Sample}

Non-probability judgement sampling was used with sample members selected based on whether they were trailing spouses currently accompanying an expatriate on an international assignment. These spouses were considered to be in the best position to respond to their needs as well as to what they received from the MNE.

Initially 196 MNEs were contacted to determine whether or not they made use of expatriate employees. For those enterprises that employed expatriates, the relevant human resource or expatriate manager was contacted telephonically or via email to request their assistance with distributing details of the study to expatriate spouses. Only 17 of these enterprises provided formal consent for their expatriates' spouses to participate in the study.

Snowball sampling, although not initially intended as a sampling method, was also used, as trailing spouses who completed the questionnaire encouraged others within their networks to participate in the research. International relocation enterprises, foreign expatriate organisations, expatriate online forums, and expatriate LinkedIn and Facebook groups were also contacted to assist in connecting with potential respondents.

Finally, 443 responses were received, of which 218 were valid for data analysis. Due to the nature of the sampling, the response rate could not be determined as it could not be confirmed how many trailing spouses received the link to the online questionnaire.

\section{Data analysis}

Firstly, an exploratory factor analysis was conducted to determine whether each of the constructs represented a single or multiple factors. Next the internal consistency of the measurement tool was tested using Cronbach's alpha. This was followed by an individual $t$-test to determine if there were statistically significant differences between the preparation, training and support requirements of expatriate trailing spouses and the preparation, training and support that they were provided with. Lastly, a paired $t$-test was conducted to determine if there were statistically significant differences between the mean scores of the preparation and training requirements and that which was provided to the trailing spouses.

\section{Ethical considerations}

This article followed all ethical standards for carrying out research without direct contact with human or animal subjects. 


\section{Results \\ Demographic profile of the sample}

Table 1 summarises the most important demographic characteristics of the sample. From this it can be seen that the trailing spouse in this study were predominantly female $(91.7 \%)$, were between the ages of 41 and $50(35.3 \%)$ and $42.7 \%$ felt adjusted to the host country. Additionally, $72.9 \%$ of the respondents were employed before the assignment, while only $20.6 \%$ were employed during the assignment. Lastly, the respondents were assigned to six different continents and 52 different countries, Asia being the most represented continent, represented by $40.6 \%$ of the respondents, followed by Africa with $35.0 \%$.

\section{Exploratory factor analysis}

The number of factors was determined by how many factors had eigenvalues greater than 1 (Pallant 2010:192). Consequently, one factor emerged each for preparation required and preparation provided prior to departure and one factor each for training required and training provided prior to the assignment. Support required and the support provided during the assignment consists of two factors each. Each variable under support required and support provided was classified under the factor where it loaded the highest, with Table 2 providing a summary of the exploratory factor analysis results.

\section{Reliability}

In total there were 22 variables measuring the preparation, training and support required by trailing spouses and that which was provided to them by the MNE. Table 3 provides a summary of the Cronbach's alpha values of the variables measuring required factors and those provided for each of them. According to Milfont and Gouveia (2006:76) and Tappen (2010:131), a Cronbach's alpha value that is above 0.70 is regarded as an indication of reliability. As can be seen from Table 3, a Cronbach's alpha value greater than 0.70 was achieved for all of the factors.

\section{Preparation required versus provided}

All five of the preparation variables showed statistically significant differences $(p<0.0001)$ between the preparation required by trailing spouses and the preparation provided to them, with the mean scores for what was required all being greater than the mean scores for what was provided (see Table 4).

\section{Training required versus provided}

All four of the training variables showed statistically significant differences $(p<0.0001)$ between the training required by trailing spouses and the training provided to them, with all the mean scores for training required being higher than the mean scores for training provided (see Table 5).

\section{Support required versus provided}

The study found statistically significant differences $(p<0.0001)$ between the support required by trailing spouses
TABLE 1: Sample characteristics.

\begin{tabular}{|c|c|c|}
\hline Variable & Frequency & $\%$ \\
\hline \multicolumn{3}{|l|}{ Gender } \\
\hline Male & 18 & 8.3 \\
\hline Female & 200 & 91.7 \\
\hline \multicolumn{3}{|l|}{ Age } \\
\hline $20-30$ years & 23 & 10.6 \\
\hline $31-40$ years & 50 & 22.9 \\
\hline $41-50$ years & 77 & 35.3 \\
\hline $51-60$ years & 32 & 14.7 \\
\hline $61-70$ years & 7 & 3.2 \\
\hline Missing & 29 & 13.3 \\
\hline \multicolumn{3}{|l|}{ Were you involved during the selection process? } \\
\hline No, not at all & 112 & 51.4 \\
\hline To some extent & 81 & 37.2 \\
\hline Yes, completely & 24 & 11.0 \\
\hline Missing & 1 & 0.5 \\
\hline \multicolumn{3}{|l|}{ Do you have children at school? } \\
\hline Yes & 106 & 48.6 \\
\hline No & 112 & 51.4 \\
\hline \multicolumn{3}{|l|}{ If yes are they accompanying you on the assignment? } \\
\hline Yes & 103 & 47.2 \\
\hline No & 2 & 1.9 \\
\hline Missing & 1 & 0.9 \\
\hline \multicolumn{3}{|l|}{ Length of time between selection and departure } \\
\hline Less than 1 month & 12 & 5.5 \\
\hline $1-6$ months & 148 & 67.9 \\
\hline $7-12$ months & 24 & 11.0 \\
\hline 13 months or more & 28 & 12.8 \\
\hline Missing & 6 & 2.8 \\
\hline \multicolumn{3}{|l|}{ Trailing spouse employed before the assignment } \\
\hline Yes & 159 & 72.9 \\
\hline No & 59 & 27.1 \\
\hline \multicolumn{3}{|l|}{ Are you currently employed while on assignment? } \\
\hline Yes & 45 & 20.6 \\
\hline No & 173 & 79.4 \\
\hline \multicolumn{3}{|l|}{ What is your level of adjustment to the host country? } \\
\hline Highly unadjusted & 9 & 4.1 \\
\hline Unadjusted & 4 & 1.8 \\
\hline Coping & 52 & 23.9 \\
\hline Adjusted & 93 & 42.7 \\
\hline Highly adjusted & 60 & 27.5 \\
\hline \multicolumn{3}{|l|}{ Proficiency in the host language prior to the assignment } \\
\hline Could not speak the language at all & 111 & 50.9 \\
\hline Could speak and understand the language in a limited way & 24 & 11.0 \\
\hline Could understand the language used in everyday situations & 8 & 3.7 \\
\hline Could communicate in a range of everyday social and travel contexts & 7 & 3.2 \\
\hline Could speak the language with confidence & 12 & 5.5 \\
\hline Could use the language in a range of culturally appropriate ways & 5 & 2.3 \\
\hline Could speak, read and write the language with fluently and ease & 49 & 22.5 \\
\hline Missing & 2 & 0.9 \\
\hline \multicolumn{3}{|l|}{ What is the location of the MNE's head office? } \\
\hline Africa & 47 & 21.6 \\
\hline Asia & 30 & 13.8 \\
\hline Europe & 73 & 33.5 \\
\hline North America & 49 & 22.5 \\
\hline Oceania & 8 & 3.7 \\
\hline South America & 1 & 0.5 \\
\hline Missing & 10 & 4.6 \\
\hline
\end{tabular}

MNE, multinational enterprise.

and the support provided to them, with all the mean scores for support required being higher than the mean scores for support provided (see Table 6). 
TABLE 2: Combined results of the exploratory factor analysis.

\begin{tabular}{|c|c|c|c|c|}
\hline Construct & Factor description & Eigenvalue & Variance explained by individual factors (\%) & Cumulative variance (\%) \\
\hline Preparation required & Preparation required & 2.85 & 57.03 & 57.03 \\
\hline Preparation provided & Preparation provided & 2.56 & 51.22 & 51.22 \\
\hline Training required & Training required & 2.93 & 73.25 & 73.25 \\
\hline Training provided & Training provided & 3.05 & 76.24 & 76.24 \\
\hline Support required & Vocational support required & 7.245 & 55.73 & 55.73 \\
\hline Support required & Social support required & 1.278 & 9.83 & 65.56 \\
\hline Support provided & Practical support provided & 6.43 & 49.44 & 49.44 \\
\hline Support provided & Employment support provided & 1.13 & 8.71 & 58.15 \\
\hline
\end{tabular}

TABLE 3: Factor reliability as described by the Cronbach's alpha values.

\begin{tabular}{lcc}
\hline Factor description & Cronbach's alpha value & Number of items \\
\hline Preparation required & 0.808 & 5 \\
Preparation provided & 0.753 & 5 \\
Training required & 0.877 & 4 \\
Training provided & 0.895 & 4 \\
Vocational support required & 0.908 & 6 \\
Social support required & 0.889 & 7 \\
Practical support provided & 0.866 & 9 \\
Employment support provided & 0.852 & 4 \\
\hline
\end{tabular}

\section{Paired $t$-test}

A paired $t$-test was conducted for the preparation required versus preparation provided factors as well as for the training required versus training provided factors. The test could, however, not be conducted for the support construct, as the two factors making up the support required construct and the two factors making up the support provided construct consisted of different variables.

When looking at the results, a statistically significant difference was found between the preparation required by trailing spouses and the preparation provided to them by the MNE $(t$-value $=15.705)(p<0.0001)$. A statistically significant difference was also found between the training required by trailing spouses and that which was provided to them by the $\operatorname{MNE}(t$-value $=13.945)(p<0.0001)$. These paired $t$-test results support the results of the individual $t$-test by showing that MNEs are not providing trailing spouses with the preparation or training that they require prior to an assignment.

Consequently, the following hypotheses could not be accepted:

$\mathbf{H}_{\mathbf{1}}$ : There is no difference between the preparation required by trailing spouses and the preparation provided to them by the multinational enterprise prior to the assignment.

$\mathbf{H}_{2}$ : There is no difference between the training required by trailing spouses and the training provided to them by the multinational enterprise prior to the assignment.

Although a paired $t$-test could not be conducted to test the support hypotheses, it is clear from the individual $t$-test results that the trailing spouses in this study do not perceive the MNEs to be meeting their support requirements.

\section{Descriptive statistics}

All the variables focusing on preparation required had a mean score of above 2.5 on a four-point scale, with 'advance notice of relocation' being the most required preparation requirement (see Table 7).

Meanwhile 'training regarding similarities and differences between the home and host countries' objective characteristics' was the training variable most required by trailing spouses (see Table 8). Objective training refers to observable and tangible characteristics of a culture such as currency, architecture, and so forth, as opposed to subjective characteristics such as punctuality, attitude to work and the like (Shay \& Tracey 1997:34-35).

Financial support to further the trailing spouse's education was the most required vocational support requirement (see Table 9), while enterprise-provided visas, work permits and so on was the social support most required by trailing spouses (see Table 10).

\section{Discussion}

The expatriate literature suggests that the preparation, training and support of trailing spouses will improve their adjustment to the host country and consequently the success of the international assignment. Having said this, decades after first identifying trailing spouses as the primary cause of expatriate failure, this study has found that MNEs are still falling short of the preparation, training and support needs of trailing spouses.

In particular, this study has found that the largest discrepancy between the preparation required and provided to trailing spouses was for information sessions covering cultural differences between the home and the host country, followed by the need for reading material on the host country, both emphasising their need for information on the host location. These findings support the literature which emphasises the importance of information sessions to enable spouses to understand what it means to live in the host country and to foresee potential issues that might arise, thus enhancing their cross-cultural adjustment (Miser 2010:4; Simeon \& Fujiu 2000:597; Yu et al. 2005:191).

Advance notice, despite being the preparation requirement with the highest mean score, was found to be the preparation requirement with the smallest difference between what was required and what was provided to trailing spouses, which highlights a focus on the operational aspects of an assignment. With an increase in dual-career couples, sufficient notice to explore career options in the host country before deciding whether or not to accept an international assignment is vital 
TABLE 4: Individual $t$-test results for preparation required versus preparation provided.

\section{Variables}

Information sessions covering cultural differences between the home and host countries (for example, eating habits, festivities,

housing, schooling and safety concerns)

Detailed reading material on the host country (for example, its history, economy and customs)

Orientation visit to the host country prior to departure

Contact with spouses already on assignment in the host country

Advance notice of relocation to allow for sufficient preparation

\begin{tabular}{ccc}
$\boldsymbol{t}$ & $\boldsymbol{p}$ & Mean difference \\
\hline 13.312 & $<0.0001$ & 1.09174 \\
& & \\
12.581 & $<0.0001$ & 1.01835 \\
11.324 & $<0.0001$ & 0.94037 \\
11.150 & $<0.0001$ & 0.88991 \\
8.494 & $<0.0001$ & 0.54128 \\
\hline
\end{tabular}

TABLE 5: Individual $t$-test results for training required versus training provided.

\begin{tabular}{lcc}
\hline Variables & $\boldsymbol{t}$ & Mean difference \\
\hline $\begin{array}{l}\text { Training regarding similarities and differences between the home and host countries' objective characteristics } \\
\text { (for example, currency, political system, architecture) }\end{array}$ & 1.07339 & $<.134$ \\
$\begin{array}{lc}\text { Training regarding similarities and differences between the home and host cultures' subjective characteristics } \\
\text { (for example, social behaviour, lifestyles, customs, values and belief systems) }\end{array}$ & 13.265 & $<0.0001$ \\
Basic courses in the host language prior to departure & 1.02752 & 11.539 \\
Language manuals, tapes, CDs, dictionaries, etc. & $<0.0001$ & 0.93578 \\
\hline
\end{tabular}

TABLE 6: Individual $t$-test results for support required versus support provided.

\begin{tabular}{|c|c|c|c|}
\hline Variables & $t$ & $p$ & Mean difference \\
\hline Employment counselling in the host country & 14.364 & $<0.0001$ & 1.22936 \\
\hline Introductions into expatriate spousal social networks in the host country & 13.946 & $<0.0001$ & 1.17890 \\
\hline Employment assistance through formal recommendations & 14.185 & $<0.0001$ & 1.11468 \\
\hline Club memberships (sport, cooking, hobby or social clubs) & 13.798 & $<0.0001$ & 1.09174 \\
\hline Tour of the host country on arrival & 13.674 & $<0.0001$ & 1.08257 \\
\hline Financial support for further education & 12.760 & $<0.0001$ & 1.08257 \\
\hline Compensation for lost wages & 12.496 & $<0.0001$ & 1.06422 \\
\hline Coach or mentor during the assignment & 13.085 & $<0.0001$ & 1.05963 \\
\hline Employment assistance within the enterprise & 12.763 & $<0.0001$ & 1.05046 \\
\hline Repatriation debriefing and counselling in preparation for the return home & 13.181 & $<0.0001$ & 1.05046 \\
\hline Introductions to host nationals (locals) on arrival & 12.591 & $<0.0001$ & 0.97706 \\
\hline Enterprise-provided visas, work permits, etc. for the host country & 6.949 & $<0.0001$ & 0.55505 \\
\hline Accommodation within an expatriate community/compound in the host country & 5.973 & $<0.0001$ & 0.44954 \\
\hline
\end{tabular}

TABLE 7: Mean scores for preparation required.

\begin{tabular}{|c|c|c|}
\hline Variable & $\begin{array}{l}\text { Mean } \\
\text { score }\end{array}$ & $\begin{array}{l}\text { Standard } \\
\text { deviation }\end{array}$ \\
\hline $\begin{array}{l}\text { Advance notice of relocation to allow for sufficient } \\
\text { preparation }\end{array}$ & 3.450 & 0.6580 \\
\hline Orientation visit to the host country prior to departure & 3.280 & 0.9454 \\
\hline $\begin{array}{l}\text { Contact with spouses already on assignment in the } \\
\text { host country }\end{array}$ & 3.106 & 0.7991 \\
\hline $\begin{array}{l}\text { Detailed reading material on the host country } \\
\text { (for example, its history, economy and customs) }\end{array}$ & 3.055 & 0.8515 \\
\hline $\begin{array}{l}\text { Information sessions covering cultural differences between } \\
\text { the home and host countries (for example, eating habits, } \\
\text { festivities, housing, schooling and safety concerns) }\end{array}$ & 3.018 & 0.8797 \\
\hline
\end{tabular}

TABLE 8: Mean scores for training required.

\begin{tabular}{lcc}
\hline Variable & $\begin{array}{c}\text { Mean } \\
\text { score }\end{array}$ & $\begin{array}{c}\text { Standard } \\
\text { deviation }\end{array}$ \\
\hline $\begin{array}{l}\text { Training regarding similarities and differences between } \\
\text { the home and host countries' objective characteristics } \\
\text { (for example, currency, political system, architecture) }\end{array}$ & 2.908 & 0.9010 \\
$\begin{array}{l}\text { Training regarding similarities and differences between } \\
\text { the home and host cultures' subjective characteristics } \\
\text { (for example, social behaviour, lifestyles, customs, } \\
\text { values and belief systems) }\end{array}$ & 2.862 & 0.9255 \\
$\begin{array}{l}\text { Basic courses in the host language prior to departure } \\
\text { Language manuals, tapes, CDs, dictionaries etc. }\end{array}$ & 2.711 & 0.9949 \\
\hline & 2.537 & 0.9653 \\
\hline
\end{tabular}

(Moore 2002:64). The longer in advance the notice, the better prepared the spouses will be to cope with their relocation (Forster 2000:69; Spera 2009:289).

With Sims and Schraeder (2004:76) stating that managers believe pre-departure training for spouses is often ineffective in reducing culture shock, it is interesting to note that the
TABLE 9: Mean scores for vocational support required.

\begin{tabular}{|c|c|c|}
\hline Variable & $\begin{array}{l}\text { Mean } \\
\text { score }\end{array}$ & $\begin{array}{l}\text { Standard } \\
\text { deviation }\end{array}$ \\
\hline Financial support for further education & 2.931 & 0.9600 \\
\hline Employment assistance through formal recommendations & 2.917 & 0.9221 \\
\hline Employment counselling in the host country & 2.894 & 0.9757 \\
\hline $\begin{array}{l}\text { Repatriation debriefing and counselling in preparation for } \\
\text { the return home }\end{array}$ & 2.885 & 0.9458 \\
\hline Employment assistance within the enterprise & 2.876 & 1.0015 \\
\hline Compensation for lost wages & 2.858 & 0.9991 \\
\hline
\end{tabular}

TABLE 10: Mean scores for social support required.

\begin{tabular}{|c|c|c|}
\hline Variable & $\begin{array}{l}\text { Mean } \\
\text { score }\end{array}$ & $\begin{array}{l}\text { Standard } \\
\text { deviation }\end{array}$ \\
\hline Enterprise-provided visas, work permits etc. for the host country & 3.404 & 0.8600 \\
\hline $\begin{array}{l}\text { Introductions into expatriate spousal social networks in } \\
\text { the host country }\end{array}$ & 3.151 & 0.9006 \\
\hline Tour of the host country on arrival & 3.110 & 0.8184 \\
\hline Club memberships (sport, cooking, hobby or social clubs) & 2.991 & 0.9107 \\
\hline $\begin{array}{l}\text { Accommodation within an expatriate community/compound } \\
\text { in the host country }\end{array}$ & 2.922 & 0.9830 \\
\hline Introductions to host nationals (locals) on arrival & 2.890 & 0.8461 \\
\hline Coach or mentor during the assignment & 2.839 & 0.8939 \\
\hline
\end{tabular}

largest differences between training required by spouses and what was provided to them were for objective and subjective cross-cultural training. Enterprises are therefore falling short not only in terms of the need for information on the host country, but also in terms of providing the cultural training that expatriate spouses require. Thus, a number of studies have emphasised the importance of training programmes to 
improve spousal adjustment (Gupta et al. 2012b:1053; Konopaske \& Werner 2005:1161; Miser 2010:2; Mohr \& Klein 2004:1197), as these training programmes would reduce uncertainty and ease adjustment into the local environment (Cho et al. 2013:1053; Gupta et al. 2012b:18; Jenkins \& Mockaitis 2010:2696; Smart 2011:90). In particular, training on the host country's objective characteristics was found to be not only the variable with the biggest difference between what was required and ultimately provided, but also the training variable most required by trailing spouses.

Although language training allows spouses to effectively communicate with host country nationals and consequently helps them form friendships and cope with everyday tasks (Mohr \& Klein 2004:1194; Sharma 2012:16), of the four types of training tested in this study, language training was found to be the least sought-after requirement. This could, however, be attributed to the fact that $51.4 \%$ of the trailing spouses were able to speak the host country language prior to the assignment.

In an earlier study by Moore (2002:63), it was found that 73\% of dual-career couples considered spousal employment opportunities a major factor when deciding to accept an international assignment. However, only a quarter of spouses reported having received career assistance from the MNE. Based on the finding of this study, this seems to still be a problem, with the largest gap between support required and support provided being for 'employment counselling'; spouses feel they need counselling in order to establish or advance their career during the assignment. Financial support for education enhancement and enterprise-provided visas or work permits were two other important requirements. In both cases, these would enable trailing spouses to upgrade their skills, gain international experience and further their careers prior to repatriation. Spouses who are unable to work in the host country may become bored and frustrated and often experience a loss of professional status and self-esteem, which affects their ability to adjust (Mohr \& Klein 2004:1193; Shaffer \& Harrison 2001:241; Wilson 2011:38).

The findings also indicate a large gap in terms of introducing spouses into expatriate spousal networks, with these networks allowing spouses to get feedback and advice, form friendships and share experiences with others (Fischlmayr \& Kollinger 2010:472; Long 2010:178; Wilson 2011:18).

Multinational enterprises focusing on the operational adjustment of spouses over social adjustment was again highlighted, with the smallest discrepancy in respect of support required and provided being for 'accommodation within an expatriate community/compound in the host country'.

A surprising finding was, however, that the least required social support requirement was for a coach or mentor during the assignment as mentoring programmes have been found to relieve stress and anxiety and assist with problem solving
(Kupka et al. 2008:1771; Miser 2010:5). An introduction into expatriate spousal social networks was, however, the second most required social support requirement; possibly indicating that spouses prefer informal mentoring over formal mentoring.

In conclusion, the findings of this study show that even though we have been aware of the fact that trailing spouses are the most common reason for the failure of expatriate assignments and we are well aware of the needs of trailing spouses, MNEs are still not providing sufficient preparation, training and support to them. Seemingly, MNEs rather focus on the operational aspects of the assignment and fall short in trailing spouses' social adjustment needs, supporting an earlier finding by McNulty (2012:430).

\section{Limitations of the study}

Although the respondents in this study were assigned to six continents and 52 countries, a possible limitation of the study is that North America, Oceania and South America were under-represented as host locations compared to Africa, Asia and Europe.

Finally, the study only focused on trailing spouses who at the time of the study were on an international assignment. These spouses were considered to be in the best position to identify their preparation, training and support needs as well as what they were offered by the MNE. However, a more comprehensive view of the current situation might be gained by extending this study to the expatriate managers of MNEs as well as repatriated trailing spouses.

\section{Acknowledgements}

The financial assistance of the National Research Foundation (NRF) towards this research is hereby acknowledged. Opinions expressed and conclusions arrived at are those of the authors and are not necessarily to be attributed to the NRF.

\section{Competing interests}

The authors declare that they have no financial or personal relationships that may have inappropriately influenced them in writing this article.

\section{Authors' contributions}

The problem was conceptualised by both E-L.W. and A.J.V., while E-L.W. was primarily responsible for the data collection and analysis with the assistance of A.J.V. The first rough draft of the article was produced by E-L.W. after which A.J.V. was responsible for writing the final article.

\section{Funding information}

The financial assistance of the NRF towards this research is hereby acknowledged. Opinions expressed and conclusions arrived at are those of the authors and are not necessarily to be attributed to the NRF. 


\section{Data availability statement}

The data will be stored in accordance with the institutional policy for the preservation and retention of research data.

\section{Disclaimer}

The views expressed in this article are those of the authors and not an official position of the institution or funder.

\section{References}

Ali, A., Van der Zee, K. \& Sanders, G., 2003, 'Determinants of intercultural adjustment among expatriate spouses', International Journal of Intercultural Relations 27(5), 563-580. https://doi.org/10.1016/S0147-1767(03)00054-3

Anderson, B.A., 2005, 'Expatriate selection: Good management or good luck?', The International Journal of Human Resource Management 16(4), 567-583. https:// doi.org/10.1080/09585190500051647

Andreason, A.W., 2008, 'Expatriate adjustment of spouses and expatriate managers: An integrative research review', International Journal of Management 25(2), 382-395.

Briscoe, D.R., Schuler, R.S. \& Claus, L., 2009, International human resource management: Policies and practices for multinational enterprises, Routledge, New York.

Brown, R.J., 2008, 'Dominant stressors on expatriate couples during international assignments', The International Journal of Human Resource Management 19(6), 1018-1034. https://doi.org/10.1080/09585190802051303

Caligiuri, P., Tarique, I. \& Jacobs, R., 2009, 'Selection for international assignments', Human Resource Management Review 19(3), 251-262. https://doi.org/10.1016/j. hrmr.2009.02.001

Cascio, W.F., 2006, Managing human resources: Productivity, quality of work life, profits, 7th edn., McGraw-Hill, New York.

Cherry, J., 2010, 'International adjustment, met expectations and cultural novelty: The family dimension of promoting IFDI in South Korea', Asian Business \& Managemen 9(1), 127-147. https://doi.org/10.1057/abm.2009.25

Cho, T., Hutchings, K. \& Marchant, T., 2013, 'Key factors influencing Korean expatriates' and spouses' perceptions of expatriation and repatriation', The Internationa Journal of Human Resource Management 24(5), 1051-1075. https://doi.org/10.1 080/09585192.2012.725079

Cole, N.D., 2012, 'Expatriate accompanying partners: The males speak', Asia Pacific Journal of Human Resources 50(3), 308-326. https://doi.org/10.1111/j.17447941.2012.00024.x

Crowne, K.A. \& Goeke, R.J., 2012, 'Utilizing online social networks for expatriate's families', International Journal of Business and Social Science 3(16), 9-16.

Deen, M., 2011, 'The expatriate's spouse: An influential factor on international assignment success', Unpublished Master's thesis, University of Twente.

Dewald, B. \& Self, J.T., 2008, 'Cross cultural training for expatriate hotel managers: An exploratory study', International Journal of Hospitality \& Tourism Administration 9(4), 352-364. https://doi.org/10.1080/15256480802427305

Els, R.C., 2007, The success rates, and determinants, of South African expatriate managers in sub-Saharan African countries to first world countries, report, UNISA, Pretoria.

Fischlmayr, I.C. \& Kollinger, I., 2010, 'Work-life balance: A neglected issue among Austrian female expatriates', The International Journal of Human Resource Management 21(4), 455-487. https://doi.org/10.1080/09585191003611978

Forster, N., 1997, '“The persistent myth of high expatriate failure rates": A reappraisal', The International Journal of Human Resource Management 8(4), 414-433. https://doi.org/10.1080/095851997341531

Forster, N., 2000, 'Expatriates and the impact of cross-cultural training', Human Resource Management Journal 10(3), 63-78. https://doi.org/10.1111/j.1748-8583.2000. tb00027.x

Ghafoor, S., Khan, U.F., Idrees, F., Javed, B. \& Ahmed, F., 2011, 'Evaluation of expatriates performance and their training on international assignments', Interdisciplinary Journal of Contemporary Research in Business 3(5), 335-351.

Gupta, R., Banerjee, P. \& Gaur, J., 2012a, 'Exploring the role of the spouse in expatriate failure: A grounded theory-based investigation of expatriate spouse adjustment issues from India', The International Journal of Human Resource Management 23(17), 3559-3577. https://doi.org/10.1080/09585192.2011.645052

Gupta, R., Banerjee, P. \& Gaur, J., 2012b, 'A key challenge in global HRM: Adding new insights to existing expatriate spouse adjustment models', The Qualitative Report 17(88), 1-30.

Haile, S., Jones, M.D. \& Emmanuel, T., 2007, 'Challenges facing expatriate performance abroad', International Journal of Business Research 7(5), 100-105.

Harvey, M.G. \& Moeller, M., 2009, 'Expatriate managers: A historical review', International Journal of Management Reviews 11(3), 275-296. https://doi. org/10.1111/j.1468-2370.2009.00261.x
Harvey, M.G. \& Wiese, D., 1997, 'The dual-career couple: Female expatriates and male trailing spouses', Thunderbird International Business Review 40(4), 359-388. https://doi.org/10.1002/tie.4270400404

Harzing, A. \& Van Ruysseveldt, J. (eds.), International human resource management, 2nd edn., Sage, London.

Haslberger, A. \& Brewster, C., 2008, 'The expatriate family: An international perspective', Journal of Managerial Psychology 23(3), 324-346. https://doi. org/10.1108/02683940810861400

Jenkins, E.M. \& Mockaitis, A.I., 2010, 'You're from where? The influence of distance factors on New Zealand expatriates' cross-cultural adjustment', The International Journal of Human Resource Management 21(5), 2694-2715. https://doi.org/10.1 080/09585192.2010.528653

Kim, H. \& Tung, R.L., 2013, 'Opportunities and challenges for expatriates in emerging markets: An exploratory study of Korean expatriates in India', The International Journal of Human Resource Management 24(5), 1029-1050. https://doi.org/10.1 080/09585192.2012.753551

Konopaske, R., Robie, C. \& Ivancevich, J.M., 2005, 'A preliminary model of spouse influence on managerial global assignment willingness', International Journal of Human Resource Management 16(3), 405-426. https://doi.org/10.1080/ 0958519042000339570

Konopaske, R. \& Werner, S., 2005, 'US manager's willingness to accept a global assignment: Do expatriate benefits and assignment length make a difference?', The International Journal of Human Resource Management 16(7), 1159-1175. https://doi.org/10.1080/09585190500143998

Kupka, B. \& Cathro, V., 2007, 'Desperate housewives - Social and professional isolation of German expatriated spouses', The International Journal of Human Resource Management 18(6), 951-968. https://doi.org/10.1080/09585190701320908

Kupka, B., Everett, A.M. \& Cathro, V., 2008, 'Home alone and often unprepared: Intercultural communication training for expatriated partners in German MNCs', The International Journal of Human Resource Management 19(10), 1765-1791. https://doi.org/10.1080/09585190802323819

Lauring, J. \& Selmer, J., 2010, 'The supportive expatriate spouse: An ethnographic study of spouse involvement in expatriate careers', International Business Review 19(1), 59-69. https://doi.org/10.1016/j.ibusrev.2009.09.006

Long, S.I., 2010, 'Adjustment of South African expatriates in Dubai: A Gestalt approach for family and child therapy', Unpublished Doctoral thesis, Unisa.

Lund, D.W. \& Degen, R.J., 2010, 'Selecting candidates and managing expatriate assignments in China', Global Business and Organisational Excellence 30(1) 60-72. https://doi.org/10.1002/joe.20359

Mäkelä, L., Känsälä, M. \& Suutari, V., 2011, 'The roles of expatriates' spouses among dual career couples', Cross Cultural Management: An International Journal 18(2), 185-197. https://doi.org/10.1108/13527601111126012

Mansour, B.E. \& Wood, E., 2010, 'Cross-cultural training of European and American managers in Morocco', Journal of European Industrial Training 34(4), 381-392. https://doi.org/10.1108/03090591011039108

McNulty, Y., 2012, “"Being dumped in to sink or swim": An empirical study of organisational support for the trailing spouse', Human Resource Development International 15(4), 417-434. https://doi.org/10.1080/13678868.2012.721985

Mendenhall, M., Dunbar, E. \& Oddou, G.R., 1987, 'Expatriate selection, training, and career-pathing: A review and critique', Human Resource Management Journal 26(3), 331-345. https://doi.org/10.1002/hrm.3930260303

Milfont, T.L.G. \& Gouveia, V.V., 2006, 'Time perspective and values: An exploratory study of their relations to environmental attitudes', Journal of Environmental Psychology 26(1), 72-82. https://doi.org/10.1016/j.jenvp.2006.03.001

Miser, A.L., 2010, Cross-cultural coaching: Ensuring success over the life cycle of an expatriate assignment, viewed 12 February 2013, from http://www. elysianenterprises.net/wp-content/uploads/2011/09/Cross-Cultural-CoachingEnsuring-Success.pdf

Mohr, A.T. \& Klein, S., 2004, 'Exploring the adjustment of American expatriate spouses in Germany', The International Journal of Human Resource Management 15(7), 1189-1206. https://doi.org/10.1080/0958519042000238400

Moore, M.J., 2002, 'Same ticket, different trip: Supporting dual-career couples on global assignments', Women in Management Review 17(2), 61-67. https://doi. org/10.1108/09649420210421763

Okpara, J.O. \& Kabongo, J.D., 2011, 'Cross-cultural training and expatriate adjustment: A study of western expatriates in Nigeria', Journal of World Business 46(1), 22-30. https://doi.org/10.1016/j.jwb.2010.05.014

Pallant, J., 2010, SPSS survival manual: A step by step guide to data analysis using SPSS, 4th edn., McGraw-Hill Education, Berkshire, UK.

Purgal-Popiela, J., 2011, 'Adjustment of expatriates and their spouses as a challenge for international human resource management', Journal of Intercultural Management 3(1), 27-43.

Qualtrics, 2019, Flexible, powerful insight. Create advanced inline surveys, viewed 20 March 2019, from https://www.qualtrics.com/uk/lp/surveys/?utm source=google\&utm_medium $=p p c \& u t m \_c a m p a i g n=b r a n d+b m m+z a \&$ campaigni $\mathrm{d}=1729762274 \&$ utm_content $=\&$ adgroupid $=74598476144 \&$ utm keyword $=$ qualtrics $\% 20$ surveys $\&$ utm term $=$ qualtrics $\% 20$ surveys $\&$ matchtype $=\mathrm{b} \&$ keyword=qualtrics $\% 20$ surveys\&utm_term $=$ qualtrics $\% 20$ surveys $\&$ matchtype=b\&
device=c\&placement $=\&$ network $=$ g\&creative $=337461998376 \&$ gclid=EAlalQobCh device $=c \&$ placement $=\&$ network=g\&creative $=3374619983$
MIn_Cbrt2Q4QIVI4bVCh1-1gZfEAAYASAAEgJotPD_BwE

Rosenbusch, K. \& Cseh, M., 2012, 'The cross-cultural adjustment process of expatriate families in a multinational organisation: A family systems theory perspective', families in a multinational organisation: A family systems theory perspective,
Human Resource Development International 15(1), 61-77. https://doi.org/10.108 Human Resource Developm
$0 / 13678868.2011 .646895$ 
Selmer, J. \& Leung, A.L.M., 2003, 'Provision and adequacy of corporate support to male expatriate spouses: An exploratory study', Personnel Review 32(1/2), 9-21. male expatriate spouses: An exploratory study',
https://doi.org/10.1108/00483480310454691

Shaffer, M.A. \& Harrison, D.A., 2001, 'Forgotten partners of international assignments: Development and test of a model of spouse adjustment', Journal of Applied Psychology 86(2), 238-254. https://doi.org/10.1037/0021-9010.86.2.238

Shaffer, M.A., Kraimer, M.L., Chen, Y. \& Bolino, M.C., 2012, 'Choices, challenges, and career consequences of global work experiences: A review and future agenda', Journal of Management 38(4), 1282-1327. https://doi.org/10.1177/0149206312441834

Sharma, D., 2012, 'Expatriate training and development', International Journal of Management and Computing Sciences 1(4), 12-20.

Shay, J. \& Tracey, J.B., 1997, 'Expatriate managers: Reasons for failure and implications for training', Cornell Hotel and Restaurant Administration Quarterly 38(1), 30-35. https://doi.org/10.1177/001088049703800116

Shen, J., 2005, 'International training and management development: Theory and reality', Journal of Management Development 24(7), 656-666. https://doi. org/10.1108/02621710510608786

Simeon, R. \& Fujiu, K., 2000, 'Cross-cultural adjustment strategies of Japanese spouses in Silicon Valley', Employee Relations 22(6), 594-611. https://doi. org/10.1108/01425450010379216

Sims, R.H. \& Schraeder, M., 2004, 'An examination of salient factors affecting expatriate culture shock', Journal of Business and Management 10(1), 73-87.

Smart, J., 2011, 'Success: Perceptions of New Zealand expatriates in Singapore', Unpublished Masters thesis, University of Otago.

Spera, C., 2009, 'Spouses' ability to cope with deployment and adjust to air force family demands', Armed Forces \& Society 35(2), 286-306. https://doi. org/10.1177/0095327X08316150

Swarts, I. \& Du Plessis, Y., 2007, 'Job-related attitudes and expatriate managers' intention to quit a foreign assignment', Journal of Contemporary Management 4(1), 46-67.

Tappen, R.M., 2010, Advanced nursing research: From theory to practice, Jones \& Bartlett Learning, Sudbury, MA.
Templer, K.J., 2010, ‘Personal attributes of expatriate managers, subordinate ethnocentrism and expatriate success: A host-country perspective', The International Journal of Human Resource Management, 21(10), 1754-1768. https://doi.org/10.1080/09585192.2010.500493

Tung, R.L., 1981, 'Selection and training of personnel for overseas assignments', Columbia Journal of World Business 16(1), 68-78.

Tung, R.L., 1982, 'Selection and training procedures of U.S., European, and Japanese multinationals', California Management Review 25(1), 57-71. https://doi. org/10.2307/41164993

Van Erp, K.J.P., Giebels, E., Van der Zee, K.I. \& Van Duijn, M.A.J., 2011, 'Expatriate adjustment: The role of justice and conflict in intimate relationships', Persona Relationships 18(1), 58-78. https://doi.org/10.1111/j.1475-6811.2010.01312.x

Vögel, A.J. \& Van Vuuren, J.J., 2008, 'Factors influencing the preparation, support and training of South African expatriates', Acta Commercii 8(1), 80-89. https://doi. org/10.4102/ac.v8i1.69

Wang, J., Bullock, C. \& Oswald, S., 2011, 'Expatriate selection: The key to international success', International Business \& Economics Research Journal 1(11), 69-76. https://doi.org/10.19030/iber.v1i11.3999

Wilkinson, A. \& Singh, G., 2010, 'Managing stress in the expatriate family: A case study of the state department of the United States of America', Public Personnel Management 39(2), 169-181. https://doi.org/10.1177/009102601003900206

Wilson, C., 2011, The expatriate spouse: A study of their adjustment to expatriate life, viewed 12 February 2013, from http://muir.massey.ac.nz/bitstream/handle/ 10179/2852/02_whole.pdf?sequence $=1$

Wu, P. \& Ang, S.H., 2011, 'The impact of expatriate supporting practices and cultura intelligence on cross-cultural adjustment and performance of expatriates in Singapore', The International Journal of Human Resource Management 22(13), 2683-2702. https://doi.org/10.1080/09585192.2011.599956

Yu, J.C., Yi, C., Chiao, Y. \& Wei, Y., 2005, 'Toward a model of adaptation of Taiwanese expatriates' spouses in multinational corporations', International Journal of Commerce and Management 15(3), 187-204. https://doi.org/10.1108/10569 210580000196 